\title{
Financial Inclusion through Mobile Micro Banking: Building a Prototype for Transaction Cost Efficiency in Microfinance Practice
}

\section{A H M Belayeth Hussain}

Professor, Department of Sociology, Shahjalal University of Science \& Technology (SUST), Sylhet, BANGLADESH

Corresponding Contact:

Email: belayeth.hussain@gmail.com

\begin{abstract}
The present paper briefly reviews and emphasizes numerous faceted costs fitting to transaction and administration brought about by financing techniques of a microfinance establishment. The paper likewise proposes a model that can utilize the digital device to diminish different expenses including social capital, observation and approvals. The paper proposes that this model can be an option road for financial inclusions and repayment achievement of lending establishments at the expense cost of transaction and administrative cost.
\end{abstract}

Key Words: Mobile banking, microfinance, prototype, financial inclusion, transaction costs

\section{INTRODUCTION}

Amid the 1990s, the neo-liberal perspective of social performance promoted non-sponsored, outreached, profitable and financially sustainable microfinance organizations (MFIs). On the premise of social and financial performance indicators, the MFIs around the developing world composed and offered their money related administrations and different intermediations to the rural poor. So as to convey these administrations to clients, the microfinance business focused on the rural poor, particularly rural women, to give them access to financial services, which was missing in the established financial framework. Also, enhancing and using social and political capital of the rural poor make an "effective" repayment process and general administration of the MFIs. The MFIs use them as a security against the issues of aggregate activity, pioneer practices and financial dangers all in all (Zeller, Lapenu and Greeley, 2003, p. 5-6). This certification, which has been named social guarantee in rural villages, likewise limits the managerial and transaction cost of the lending insitutions (Rahman, 1999, p. 69-71). The present paper quickly surveys and underscores different features of transaction and organization costs brought about by the financial strategies of loaning organizations. A portion of the issues important to transaction and regulatory cost are benefits of social capital, thorough reconnaissance performed by MFI staff and clients, and diverse types of authorizations if there should arise an occurrence of stubborn defaults. Further, the paper proposes an option road for repayment accomplishment at the least expense of the transaction and administrative cost. 


\section{Transaction Cost}

Since microcredit groups depend on joint-risk among themselves, this common obligation of borrowers is considered as a financial intermediary where the welfare of a borrower is adversely influenced by the poor performance of different borrowers (Bond, 2004, p. 383). As a method, these intermediaries are additionally considered 'designated monitors', in which as opposed to checking by the loaning establishments, the errand of observing is doled out to a solitary mediator (the credit assemble on the premise of joint risk). The MFI specialists delegate the elements of screening, observing and implementation of repayment process to the borrowers themselves (Bond, 2004, p. 383; Sharma, 1997, p. 1734). Since on one hand a borrower's entrance to further credit relies on upon the success of the bank, the success of the bank likewise relies on upon the borrower's colleagues then again (Bond, 2004, p. 384).

In the current credit model, with a specific end goal to guarantee catch up credit, the MFIs urge their individuals to perform distinctive capacities, including the screening of loan applications, checking borrowers' status of speculation, and additions and misfortunes of an individual borrower (Zeller, 1998, p. 599). Along these lines, colleagues exchange important data for MFI specialists that could be generally difficult to gather by MFI staff. Karlan (2007, p. 57), be that as it may, arrives at an alternate conclusion and contends that observing does not ensure repayment yet rather encourages MFIs to know who is to be rebuffed for not repaying. He recognizes a few methods for checking borrower exercises: watching repayment of the loan, going to a kindred's venture to confirm its condition of operation and additionally sharing data about any sudden ailment or other unexpected conditions which may bring about a postponement or default of loan repayment.

Keeping in mind the end goal to guarantee the most extreme advantages of choosing group members, maintaining a strategic distance from unfriendly choice is the way to fruitful repayment. In this way, the distinguishing proof procedure is critical to fruitful group arrangement in light of the fact that the determination issue is fundamental among different issues including expensive confirmation, contract implementation, and high transaction cost of smaller scale loaning (Jain, 2003, p. 260). Because of the data asymmetries and social collaborations among individuals, moral perils and key defaults wind up noticeably troublesome for group members (Godquin, 2004, p. 1910). Alluding to the World Bank provide details regarding a Latin American plan, Besley and Coate (1995, p. 9) bolsters the subjective choice of group members is probably not going to accomplish amass obligation, and along these lines, the arrangement demonstrated unsuccessful. Since the current small scale loaning procedure experiences these issues, the present model recommends an alternative to decrease this determination issue utilizing an application (App) through cell phone.

Hermes et al. (2005, p. 149) explore the part of observing and social ties on credit repayment and find that observing by group leaders has more effect on checking moral perils. Authors additionally allude to Wydick's (1999) inquire about discovering, which has distinctive outcomes. The discoveries demonstrate that while peer observing and [to a lesser extent] peer pressure help to diminish moral risk and increment the repayment performance of group, social ties do not have such impacts (Hermes et al, 2005, p. 149). Data stream about a client is important to shield from misconduct as Conning $(1999$, p. 55) predicts that the potential issue of peril develops when a business visionary tries to get outside back for her venture [for extra financing]. In this manner, various affiliations to extra MFIs may bring venture disappointment. At present accessible literature does not address the issue of data stream and channel about any instance of that sort. My proposed model cases to disconnect every borrower, utilizing versatile Apps, from going into another MFI. 
A tight timetable of repayment is a 'financial teach' among borrowers that stems from possibilities of 'good perils' of borrowers (Jain and Mansuri, 2003, p. 253). Further, financial teach permits an MFI to make utilization of the predominant observing ability of the casual loan specialist in obliging vital conduct by the borrower (Ibid, 2003, p. 256). Jain and Mansuri (2003, p. 270-271) contend that microcredit customers embrace various strides to adapt to the financial train set by the MFIs and, in this manner, members acquire more credits from informal lenders accessible around them. Furthermore, some logical factors are essential determinants in loan repayment exercises: transaction costs confronted by borrowers, homogeneity of groups (as far as attribute and inclinations) and dangers/authorizes by the group or program in case of conceivable default (Bhatt and Tang, 2002 , p 362.). Clearly the danger of approvals by the group or loaning organizations in the event of default is sure to conform to the credit plan routinely (Bhatt and Tang, 2002, p. 367). The World Bank (1997) provide details regarding Burkina Faso demonstrates that repayment rates are high in light of the fact that the dangers of ex post peer pressure were outrageous (Ibid, 2002, p. 367). Likewise, the risk of loss of access to future credit from the loaning organizations propels customers to conform to credit premiums (Bhatt and Tang, 2002, p. 367; Muhammad, 2009, p. 41). They may likewise incorporate the risk of punishments for late or no reimbursement (Bhatt and Tang, 2002, p. 367). The proposed model might have the capacity to caution every borrower (and their kindred about her conceivable default) on the due portions. Additionally, this new model can guarantee the minimum transaction cost brought about by the borrowers. In the current loaning model, a borrower needs to go to the loan centre regardless of the possibility that it's a long way from her home (or enterprise). In the most cases, a borrower additionally needs to go to week after week meeting that may likewise require a cost of time.

In a small scale credit bunch, a few exercises happen including loan installments, saving deposits, issuing new advances, preparing in group operations and the significance of group solidarity, and checking of loan repayment by all individuals (Karlan, 2007, p. 56). In the Bangladeshi MFI model, compulsory (in some cases flexible) savings by the borrowers are huge controls by all little and medium MFIs. This model embraced a choice wherein MFIs start gathering obligatory saving deposits and in this way dispensing credit and after that includes willful savings later (Dowla and Alamgir, 2003, p. 970). The most critical thing is that borrowers can not pull back the cash they deposit until or unless they leave the association or drop their enrollment, with a few exemptions in BRAC and ASA where saving deposits can be pulled back by passing a general determination in group meeting (Dowla and Alamgir, 2003, p. 973). Nonetheless, there are some various types of sparing plans accessible. For instance, Foundation for International Community Assistance (FINCA) has a possibility for reserve funds that permits its individuals to get two dollars in return of one dollar spared: one dollar from FINCA and one dollar from the saving deposit pool (Karlan, 2007, p. 68). The proposed model could incorporate FINCA way to deal with sparing alternative, which can likewise convey (through web server) on request credit to particular client.

\section{Cost OF SURVEILLANCE}

Aside from designated observing, MFI staff have unparalleled parts in forming the direct of microcredit customers. The errands of MFI staff acquire more cost for the loaning foundations. Appropriate impetuses and administration structures of MFI staff are likewise essential for loan recuperation (Conning, 1999, p. 55). Moreover, week by week gatherings give loan officers the chance to screen the customers nearly to gather repayments and saving deposits. A microfinance customer needs to experience a thorough screening and portfolio study by a 
credit officer. Godquin (2004, p. 1917) notices that before distributing a loan to the borrower, the credit officer of the MFI surveys the default likelihood of the candidate utilizing the data he has on the borrower, the loaning bunch, nature, and the anticipated adequacy of the MFI's repayment motivators for this borrower. This procedure brings various financial expenses including selecting more field staff and keeping up branch workplaces.

The most prominent model of smaller scale loaning is based on common obligation of credit, which must be together shared by all individuals. The possibility of this obligation relies on upon nearby social capital of a village terrain, and these casual connections of rural ladies channel the information. Joint obligation is the most imperative determinant of general repayment of credit portions (Stiglitz, 1990, p. 359, 361; Varian, 1990, p. 155, 157; Wenner, 1995, p. 264-265; Conning, 1999, p. 69; Ghatak, 1999, p. 45; Zeller, 1998, p. 599; Sharma and Zeller, 1997, p. 1734; Karlan, 2007, 53). In any case, discoveries from current literature are blended. Some additionally find that gathering risk has negative or no effect on repayment success (Godquin, 2004, p. 1912-1913; Sharma and Zeller 1997, p. 1740) or may not be ideal for all groups or potentially wealthier clients (Madajewicz, 2005, in Ahlin and Jiang, 2008, p. 6). Khandker (2012, p. 2) articulates three major models of group-based micro lending grounded on moral hazards (Stiglitz, 1990), strategic default (Besley \& Coate, 1995) and adverse selection (Ghatak, 1999). It is likewise a useful strategy through which designated checking and nearby authorizes over its clients are guaranteed for auspicious repayment and assurance from any conceivable default. In spite of the fact that the effects of joint risk on repayment success are conflating, the proposed model could coordinate social attachment and joint obligation in an arrangement of virtual stage.

\section{COST OF SHAME}

In rural Bangladesh, female defaults are comparable to family unit bungle that conveys disgrace and disrespect to the families (Fernando, 2010, Forbes). Lamia Karim (2011, p. 61) contends that this shame is a desirable quality since it directs women's lead and keeps them from breaking standards of rural culture. Likewise, MFIs utilize this 'economy of shame' as a loan recovery innovation where women, if there should be an occurrence of the disappointment in repayment, are frequently freely mortified, which goes about as a form of discipline (Karim, 2011, p. 84). Imperatively, MFIs additionally profit by the advantages of social settings in rural Bangladesh where ladies are in a powerless position, and this helplessness of ladies is characterized in connection to their restricted physical mobility and their socially designed conduct, for example, modesty, aloofness and accommodation (Rahman, 1999, p. 70). In the rural culture of Bangladesh, women are regularly related to unobtrusiveness and virtue, which make a lady's respect more powerless than a man's in the public arena (Rahman, 1999, p. 70). Women's respect and its security are much esteemed, and accordingly ladies need to repay their week after week loan portions determinedly to stay away from any conceivable embarrassment in the public eye. Ladies in the town are traceable, and are more taught (detached/meek) than men; they are in this manner more solid than men for reimbursement (Rahman, 1999, p 69; Fernando, 2010, Forbes). Rankin (2006, p. 83) brings up issues regarding why mainstream development organizations promote microfinance as a program procedure where they pick ladies as neighborhood business people. The real microfinance orthodoxies underscore a 'credit just' approach and follow up financial measurement of poverty lightening specifically. Along these lines, women's credit aggregates through social capital give MFIs as an instrument to lessening their institutional transaction costs (authoritative expenses) and rousing women for repayment and financial teach (Rankin, 2006, p. 87). The MFIs diminish their institutional transaction cost along these lines at the cost of disgrace. In the present paper, the model offers a framework where open embarrassment might be truant. In any case, every borrower can distinguish their colleagues inside a similar credit group and look for help utilizing their social capital. 


\section{BACKBone OF PROTOTYPE}

Bangladesh has 160 million individuals and just 13 percent of them have financial accounts. A substantial piece of the nation remains unbanked to the rural population. In any case, thus of the development of Internet and cell phone administrations, rural individuals used to have portable saving money through mainstream banks in Bangladesh. The real support of an arrangement of operation stands on the cell phone systems. The Bangladesh Government endorsed Mobile Financial Services (MFS) utilizing the current cell phone administrators. Despite the fact that the essential point was to direct internal outside settlements to the unbanked an account populace, as of now the administrations incorporate individual toindividual, individual to business, business to individual, government to individual, individual to government and also microfinance administrations (Bangladesh Bank, 2015, http:/ / www.bangladesh-bank.org/fnansys/paymentsys/mobilefin.php; recovered on 26th May, 2015). With 25.25 million enlisted clients and 533,485 specialists, 28 banks have been working in distinctive financial administrations (Bangladesh Bank).

Among a few NGOs, Bangladesh's BRAC and Philippines' BankO are the MFIs which began (truth be told, steered) microfinance benefits through portable saving money. BankO began its operations with 2000 accomplice outlets in 2012 where installments, credits, protection and sparing items have been offered to the clients (CGAP, 2015, http://www.cgap.org/distributions/microfinance-and-versatile managing an account obscuring lines; recovered on 26th May, 2015). Then again, BRAC ran a pilot venture to see the possibility of miniaturized scale money related administrations through portable managing an account with the assistance of BKash, which is a backup association (CGAP, 2015, http://www.cgap.org/blog/can-mfis-use versatile keeping money serve-clients better; recovered on 26th May, 2015) that conveys mobile saving deposits.

In microfinance practices, the significant obstruction of conveying client cordial credit is a high volume of transaction cost inside the business. Numerous literature address this issue as a vital variable for driving clients to pay a high rate of intrigue, push them to include with a different MFIs and the abuse of social capital through mortifying rural ladies (particularly in Bangladesh). Be that as it may, by using virtual stages (utilizing App) and working together with the significant versatile administrators, microfinance foundations can accomplish their monetary maintainability by keeping up a somewhat low organization cost (transaction cost). Kiva.org has been playing out its financial services through online application, yet its real supports originate from charitable gift. In the present model, an MFI can have the capacity to run their credit conveyance exercises (counting funds, protection and even backing and other agrarian guiding). Along these lines, the present paper offers a model that may get productive transaction flow in microfinance operations.

\section{Process Summary}

A web server screens the entire procedure of exchanges. The procedure requires two sorts of utilizations: for borrower/member/customer and for cash point (which can be named point of service or POS).

How application functions for a member/customer:

- A new client/member should enroll by physically going to at the closest MFI branch office. Before permitting one to be a member, MFI staff gathers data about her from a capable individual of POS. This communication (voice/text/image) goes through an App that ensures prospective customer's detail information for MFI record. 
- Through the App, a POS gets affirmation on a client's enlistment. A POS additionally gets a client's unique USER ID. A mechanized server sends this USER ID deliberately. The initial 4 digits speak to the neighborhood postal code took after by four digits POS ID and next a four-digit client number.

- The application performs in a device with enactment once this one of a kind client ID has been entered in the App. Subsequently, the web server can have the capacity to track a member's area.

- When a member needs to apply (through App) for the loan, she gives the last four digits of client ID for affirmation. This client ID additionally works as a client secret key. Confront recognition might be a contrasting option to the number secret key.

- When a client applies for a credit, the App checks whether she is applying surprisingly. For the primary credit candidate, after a portfolio review on a client's achievability, a loan can be pulled back given that the client delivers her affirmation code before the closest POS. For a present client, the App sends a demand through the server after moment (and mechanized) checks about her past activity/reputation. In the case of everything goes well, she gets a naturally produced code (confirmation) for a credit.

- Once a client gets the confirmation code, she can get her stipulated credit from her closest POS.

- The procedure of repayment of loans takes after a similar procedure however with no contribution of MFI field staff. A client can be advised well before her due installment date. This warning can likewise be sent to every last bit of her group individuals guaranteeing every customer is being informed about any potential defaults. For the individuals who need to send their installments, they can visit a POS with their client ID. A responsible person from POS gets this cash against client's ID and sends this cash basically to the server. The client (and also POS) gets affirmation of repayment naturally.

- In case an issue emerges, a client can get in contact with a POS individual or an MFI staff utilizing this App (voice or text). Be that as it may, if there should arise an occurrence of persistent default, all group individuals get advised and are asked for to contact particular default customer(s). In a most dire outcome imaginable, a staff visits her place and tries to get additional data.

- Tracking client's area should be possible through utilizing SIM of working organizations. Since versatile administrators' part in this credit framework is viewed as essential, a SIM following framework can inform the server effectively about a client's area.

- Mobile device can be conveyed as a piece of social endeavor guarantee or any magnanimous method of activity.

- If an MFI needs to run this entire virtual stage taking after Kiva.org display, they can blend the possibility of mobile micro banking with Kiva.

The present paper proposes a model that can productively check the related expenses in microfinance practice. The pictures (see Diagram-1 and Diagram-2) indicate two periods of the model. In the first phase (see Diagram-1), a prospective loan recipient, a POS agent and an MFI staff act according to their prescribed and accepted roles. 


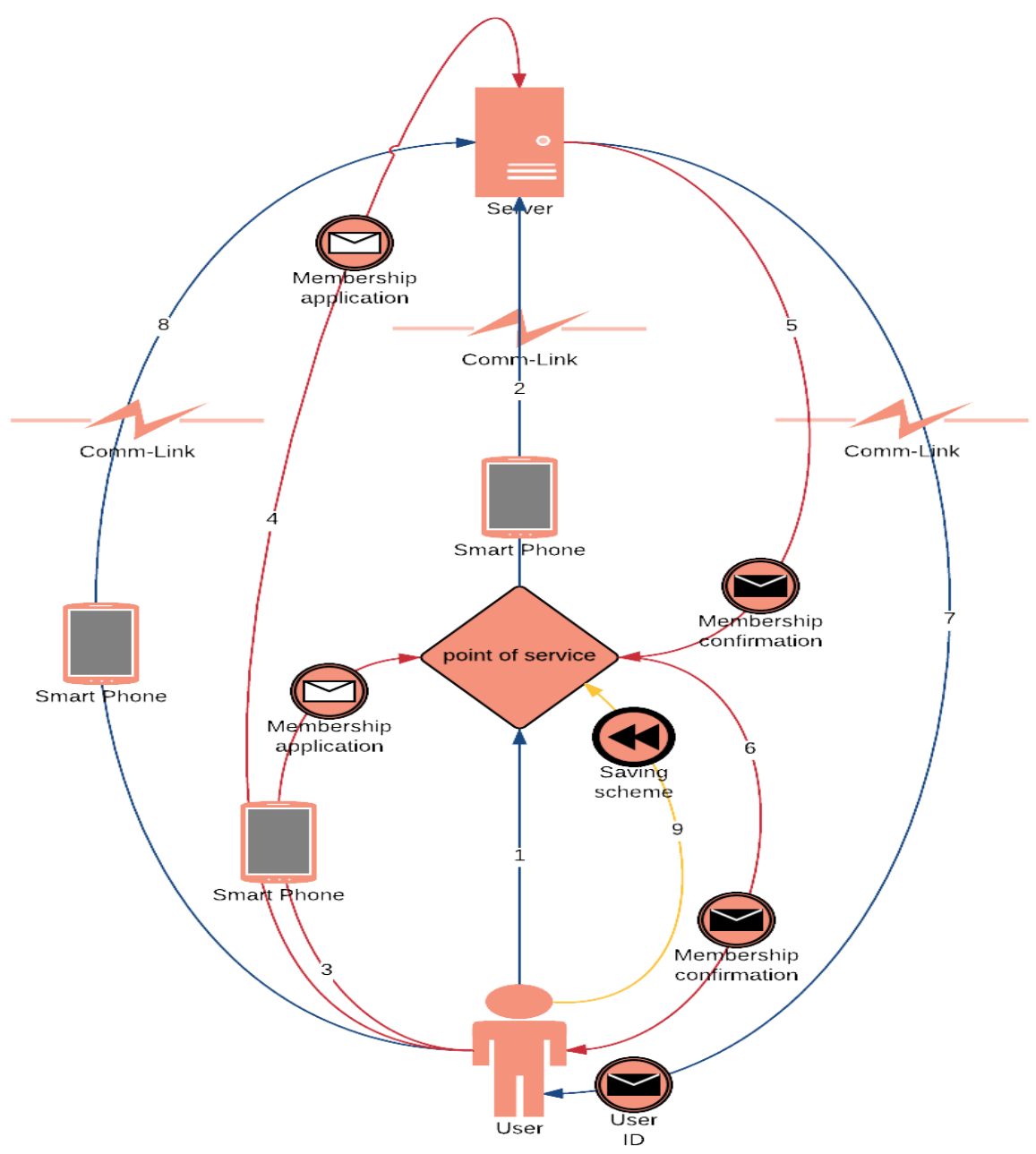

Diagram 1: Phase 1 of proposed prototype

A potential group member contacts specifically to a POS specialist or Server through her current cell phone. She can get fundamental data from other existing individuals or a POS operator. When she sends her demand (or a POS operator sends ask for her sake), she gets an answer message including some rule data. From that point onward, she contacts POS again and gives her financial and family data. An MFI staff begins a portfolio overview on an imminent member's application. At the point when the staff completes the greater part of the overview and sends the answer to the server, the lady gets another notice (effective or declined). Once a lady gets notice about her new enrollment to a specific credit group, she begins keeping saving deposit premiums for six to eight weeks. Contingent upon an MFI, a lady can store the measure of saving deposit to POS, which later consequently sends data to server. Promptly she finishes her saving deposit premiums, an MFI gives her a cell phone (counting an uncommon SIM). Then again, as we proposed, any donor association can give this device to any of the group individuals (an MFI can take after Kiva.org framework where they convey credit through benefactor. Be that as it may, in this proposed framework, a contributor can give a cell phone). Also, where pertinent a member can obtain a cell phone from the capable MFI. 
The second phase (see Diagram-2) of the model demonstrates the framework where a microcredit customer can apply, get and repay loan installments through a similar route talked about above. A part can get her endorsed credit from a POS. She can pay her portions to a POS representative. In the event of unshakable or undesirable default, a part will get notice to her cell phone (this may likewise stretch out to voice and video correspondence). In the meantime, other group individuals will likewise get messages about a similar issue. Along these lines, other general individuals from a gathering can speak with default member(s). At this phase of the microcredit procedure, an MFI staff can track a member utilizing SIM following framework (through server) for further correspondence. As we specified over, the entire framework can be founded on existing mobile operators in Bangladesh. Notwithstanding, this can likewise be bolstered by other backup online money transfer systems including BKash, which is the biggest and the most well known in Bangladesh (conceivably in different nations) (CGAP, 2015, http://www.cgap.org/blog/bkashbangladesh-what-clarifies its-quick begin, recovered on 28th May, 2015).

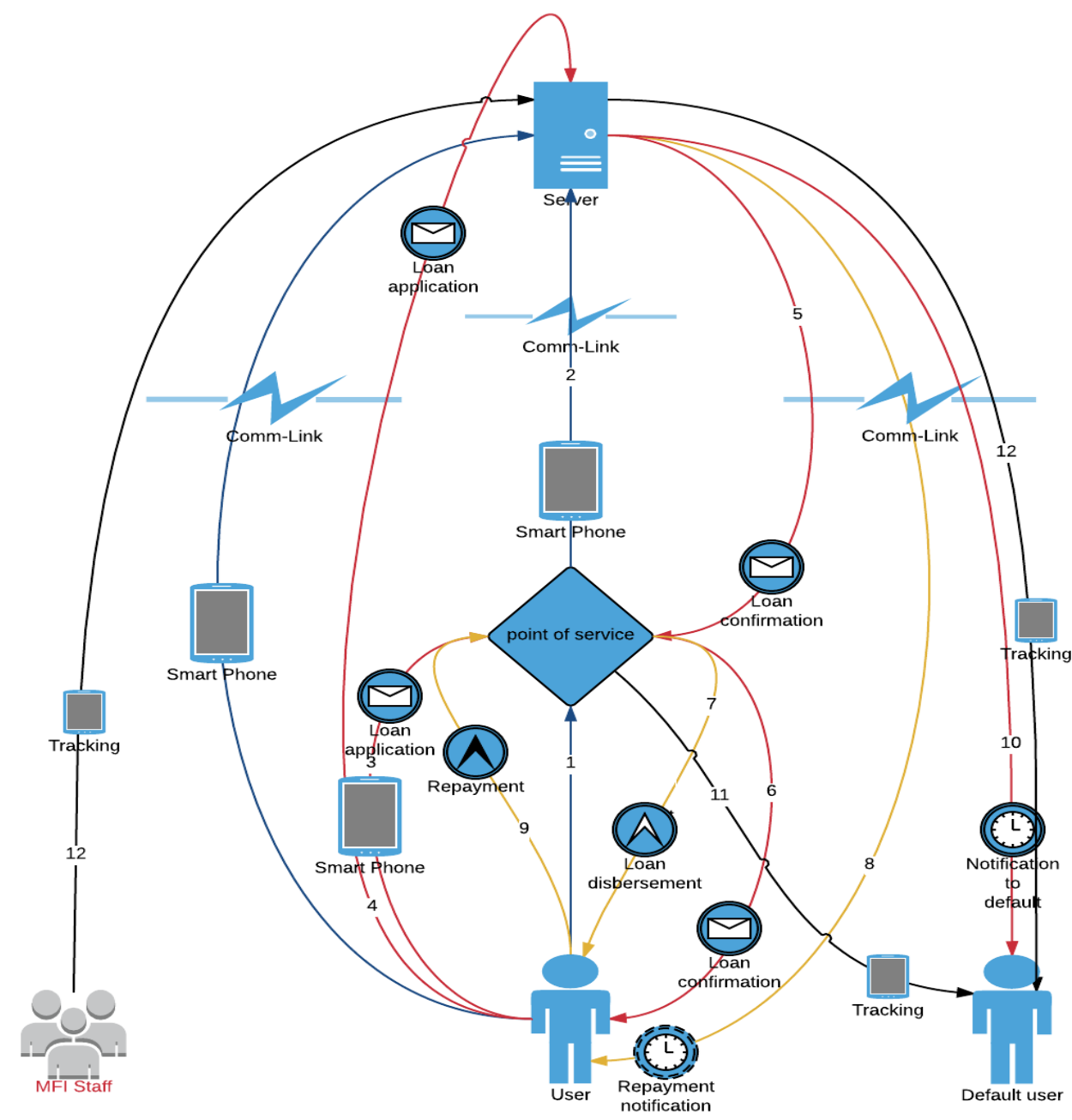

Diagram 2: Phase 2 of proposed prototype 


\section{CONCLUSIONS}

Notwithstanding appointed observing, this new model outsources additionally checking capacity to a POS specialist who has likewise a huge volume of neighborhood data about imminent and current clients. Along these lines, this model does not discount the arrangement of exorbitant check and contract execution in light of the fact that the POS operator has extra information about the financial and social foundation of an imminent customer. By taking after this model, a microfinance establishment can diminish determination inclination in a credit group. So as to manage numerous affiliations to extra MFIs, which cause mission draft in this industry, the proposed model can have the capacity to ensure this portability of customers. On the off chance that this model keeps up a crossMFI client database, this App ought to be productive in diminishing different affiliations.

Since the proposed model depends on individual loaning with group risk, it can secure two essential issues: POS can lessen going to time of customers (since they repay at POS as opposed to reimbursing at the branch or credit focus) for their week by week meeting and individuals can convey among them utilizing the virtual App alongside their standard life occasion. This can clearly disperse data to all group individuals about who could be conceivable default. Through executing this model, social capital of nearby individuals can likewise be reinforced on the grounds that they are in contact both physically and practically. As this social capital works like a social insurance, MFIs may secure their largest amount of repayment rate without bargaining transaction cost from both sides. Various literary works have been so basic to the demonstration of open mortification of default customers by their capable field staff. Be that as it may, this new model can ensure this open mortification since the clients generally convey for all intents and purposes (voice/text/video) and by and by.

The proposed prototype cannot only address the repayment issues but also savings and other advocacy functions of MFIs. A member can spare a stipulated measure of cash through utilizing this App at a POS. A member can pull back and conform advances to their saving deposits. They can likewise be protected for their venture and relatives through utilizing this model. Generally speaking, this model can decrease the directing expense of MFIs with drawing in few field staff. For further usage, by propelling this App, the MFIs can present more non-financial administrations including wellbeing and cultivating help to their clients.

\section{REFERENCES}

Ahlin, C., \& Jiang, N., 2008, 'Can Micro-credit Bring Development?', Journal of Development Economics, $86(1), 1-21$.

Bangladesh Bank, 2015. Retrieved on $26^{\text {th }}$ May, 2015 from http://www.bangladeshbank.org/fnansys/paymentsys/mobilefin.php.

Besley, T., \& Coate, S., 1995, 'Group Lending, Repayment Incentives and Social Collateral', Journal of Development Economics, 46(1), 1-18.

Bhatt, N., \& Tang, S. Y., 2002, 'Determinants of Repayment in Microcredit: Evidence from Programs in the United States', International Journal of Urban and Regional Research, 26(2), 376.

Bond, P., 2004, 'Joint Liability among Bank Borrowers', Economic Theory, 23(2), 383-394.

CGAP, 2015, retrieved on $26^{\text {th }}$ May, 2015 from http://www.cgap.org/publications/microfinance-andmobile-banking-blurring-lines

Conning, J., 1999, 'Outreach, Sustainability and Leverage in Monitored and Peer-monitored Lending', Journal of Development Economics, 60(1), 51-77. 
Dowla, A., \& Alamgir, D., 2003, 'From Microcredit to Microfinance: Evolution of Savings Products by MFIs in Bangladesh', Journal of International Development, 15(8), 988.

Fernando, J. L., 2010, 'The Myths Behind Microfinance', Forbes.com. Retrieved on $4^{\text {th }}$ April, 2015 from http://www.forbes.com/2010/12/09/microfinance-myths-muhummad-yunus-entrepreneursfinance-jude-fernando.html

Finca, 2013, 'Charitable Financial Institution', Retrieved on 22 ${ }^{\text {nd }}$ march, 2015, from http:/ /www.finca.org/site/c.6fIGIXMFJnJ0H/b.6088193/k.BE5D/Home.htm\#.UqHS0pGQflI.

Ghatak, M., 1999, 'Group Lending, Local Information and Peer Selection', Journal of Development Economics, 60(1), 27-50.

Godquin, M., 2004, 'Microfinance Repayment Performance in Bangladesh: How to Improve the Allocation of Loans by MFIs', World Development, 32(11), 1909-1926.

Hermes, N., Lensink, R., \& Mehrteab, H. T., 2005, ‘Peer Monitoring, Social Ties and Moral Hazard in Group Lending Programs: Evidence from Eritrea', World Development, 33(1), 149-169.

Jain, S., \& Mansuri, G., 2003, 'A little at a Time: The Use of Regularly Scheduled Repayments in Microfinance Programs', Journal of Development Economics, 72(1), 253-279.

Jain, S., 2003, 'The Microfinance Revolution: Sustainable Finance for the Poor', Journal of Economic Literature, 41(4), 1325-1327.

Karim, L., 2011, 'Microfinance and Its Discontents: Women in Debt in Bangladesh', Minneapolis, London, University of Minnesota Press.

Karlan, D. S., 2007, 'Social Connections and Group Banking', Economic Journal, 117(517), 52-84.

Ledgerwood, J., 1999, 'Sustainable Banking with the Poor' in Microfinance Handbook: An Institutional and Financial Perspective, The World Bank, Washington, D.C.

Muhammad, A., 2009, 'Grameen and Microcredit: A Tale of Corporate Success', Economic E Political Weekly, XLIV(35), 35-42.

Rahman, A., 1999, 'Micro-credit Initiatives for Equitable and Sustainable Development: Who Pays?', World Development, 27(1), 67-82.

Rankin, K. N., 2006, 'Social Capital, Microfinance and the Politics of Development', in J. L. FERNANDO (Ed.), Microfinance: Perils and Prospects (pp. 89-111). Oxon, New York: Routledge.

Sharma, M., \& Zeller, M., 1997, 'Repayment Performance in Group-based Credit Programs in Bangladesh: An Empirical Analysis', World Development, 25(10), 1731-1742.

Stiglitz, J. E., 1990, 'Peer Monitoring and Credit Markets', World Bank Economic Review, 4(3), 351-366.

Varian, H. R., 1990, 'Monitoring Agents with Other Agents', Journal of Institutional and Theoretical Economics, 146(1), 153-174.

Wenner, M. D., 1995, ‘Group Credit: A Means to Improve Information Transfer and Loan Repayment Performance', Journal of Development Studies, 32(2), 263-281.

Zeller, M., 1998, 'Determinants of Repayment Performance in Credit Groups: The Role of Program Design, Intragroup Risk Pooling, and Social Cohesion', Economic Development and Cultural Change, 46(3), 599-620.

Zeller, M., Lapenu, C. C., \& Greeley, M., 2003, 'Measuring Social Performance of Micro-finance Institutions: A Proposal', Argidius Foundation and Consultative Group to Assist the Poorest (CGAP). 